\title{
SUPERFÍCIES DE ENCONTRO COM O POVO INDÍGENA KARIRI-XOCÓ: IMAGENS E O DEVIR-PLANTA
}

\section{SUPERFICIES DE ENCUENTRO CON LOS INDÍGENAS KARIRI-XOCÓ: LAS IMÁGENES Y EL DEVENIR-PLANTA}

\begin{abstract}
Alik Wunder ${ }^{1}$
Resumo: Esta comunicação traz pensamentos em torno do conceito de devir a partir do encontro com narrativas, desenhos e fotografias criadas com homens e mulheres do povo indígena KaririXocó (Alagoas, Brasil) na ressonância de suas experiências com o "mundo vegetal". Há sete anos desenvolvemos na Universidade Estadual de Campinas (SP, Brasil) um projeto de intercâmbio com a aldeia Kariri-Xocó de Porto Real do Colégio (AL). Na universidade, os indígenas realizam aulas sobre seus modos de vida, cosmovisões, conhecimentos e celebrações com cantos e danças (Torés). A entrada no "mundo das plantas" Kariri-Xocó se faz em encontros de criação conjunta de imagens entre pesquisadoras e indígenas. Buscamos pensar com os filósofos Gilles Deleuze e Feliz Guattari o conceito de devir, em especial o devir-planta, e com a ideia de zona de vizinhança e inacabamento nestes encontros entre conhecimentos (acadêmicos e não-acadêmicos), entre linguagens (imagens e palavras, oralidade e escrita), entre universos culturais (indígenas e não indígenas). Buscamos pensar a experimentação imagética como uma zona de vizinhança, uma superfície de contato entre fluxos do mundo indígena, "mundo das plantas" e a filosofia.
\end{abstract}

Resumen: Esta comunicación trae pensamientos que rodean el concepto de devenir en el encuentro con narrativas, dibujos y fotografías creadas con hombres y mujeres de los indígenas Kariri-Xocó (Alagoas, Brasil) en la resonancia de sus experiencias con las plantas. Durante siete años hemos desarrollado un proyecto de intercambio con los Kariri-Xocó de Porto Real do Colégio (AL) en la Universidad Estatal de Campinas (SP, Brasil). En la universidad, los indígenas realizan clases sobre sus formas de vida, cosmovisiones, conocimientos y celebraciones con canciones y danzas (Toré). Los Kariri-Xocó nos abren a los devenires indígenas por sus cantos, imágenes, narrativas, sueños y relaciones con el universo vegetal. Modos de existir y de resistir. La entrada en el "mundo de las plantas" Kariri-Xocó se realiza en reuniones de relación conjunta de imágenes entre investigadores e indígenas. Buscamos pensar con los filósofos Gilles Deleuze y Feliz Guattari sobre el concepto de devenir, especialmente el devenir-planta, y la idea de zona inacabada en estas reuniones entre conocimiento (académico y no académico), entre lenguajes (imágenes y palabras, oralidad y escritura), entre universos culturales (indígenas y no indígenas). Buscamos pensar en la experimentación imagética como una zona de vecindario, una interfaz entre los flujos del mundo indígena, del "mundo de las plantas" y de la filosofía.

"Os devires não são fenômenos de imitação, nem de
assimilação, mas de dupla captura, de evolução não
paralela, núpcias entre dois reinos"
Gilles Deleuze

Lançamo-nos aqui a um exercício de pensamento entorno do conceito de devir e devir-planta entre narrativas, desenhos e fotografias criadas com homens e mulheres do povo indígena KaririXocó, entre as palavras dos filósofos Gilles Deleuze e Felix Guattari e Emanuele Coccia. Há sete

\footnotetext{
${ }^{1}$ Universidade Estadual de Campinas, Campinas, SP, Brasil.
} 
anos desenvolvemos na Universidade Estadual de Campinas (Unicamp) um intercâmbio com a aldeia Kariri-Xocó de Porto Real do Colégio, situada no estado de Alagoas (Brasil). Anualmente realizam na cidade de Campinas, SP, encontros em escolas e universidade sobre seus modos de vida, cosmovisões, conhecimentos e celebrações com cantos e danças intituladas Torés. Os KaririXocó abrem-nos aos devires indígenas pelos seus cantos, suas imagens, suas narrativas, seus sonhos e relações com o universo vegetal. Modos de existir e de resistir. A entrada na visualidade e no "mundo das plantas" Kariri-Xocó se faz especialmente em encontros anuais de criação conjunta de imagens - fotografias e desenhos - entre nosso grupo de pesquisa e criação (Coletivo Fabulografias - Laboratório de Estudos Audiovisuais - OLHO - Unicamp) e os indígenas, encontros que chamamos de ateliês experimentais. Abrimos, nestes anos, espaços/tempos de encontros coletivos de criação e pesquisa que se fazem entre as formas de ver e criar imagens dos Kariri-Xocó e nossos modos de ver e criar imagens. Trazemos aqui uma perspectiva de pesquisa acadêmica na qual a experimentação do pensamento dá-se no movimento inventivo com as imagens e com as palavras, de modo que as fronteiras entre pesquisa, literatura e artes visuais sejam borradas. Deseja-se manter aberta esta zona de vizinhança, na qual o pensamento acadêmico é atravessado por outros modos de expressão e percepção do mundo.

Oferecemos aos Kariri-Xocó nossas imagens, em geral fotografias e eles/elas nos oferecem as suas pinturas corporais, suas artes materiais, suas imagens de sonhos, imagens de cantos... Por meio destes encontros, estamos lentamente nos enredando e criando com o universo imagético e cosmovisões deste povo. As imagens são pensadas como travessias silenciosas, como possibilidade de coabitarmos mundos distintos no ato de criação conjunta. Imagens como superfícies de encontros, como entre mundos, como um devir, uma dupla captura entre duas visualidades. Desejamos habitar e proliferar pensamentos desde esta zona de vizinhanças, que as experimentações imagéticas traçam. A imagem - fotografias desenhos, grafismos, traços, riscos - como uma contínua experimentação, como uma forma sempre inacabada de encontrar abrindo outras linhas visuais, outras percepções e outros pensamentos.

Atualmente vivem no Brasil mais de 305 etnias indígenas e são faladas por volta de 274 línguas. Vivemos em um país multiétnico e multilinguístico. Secularmente estes povos lutam contra um processo histórico e violento de genocídio que acontece em nosso país. Os indígenas têm como principal luta a garantia do direito ao território pela demarcação das terras tradicionais, direito garantido por nossa constituição, desde 1988, e que tem sido desrespeitado há décadas e, em especial, nesse difícil momento político que vivemos no Brasil, no qual diversas políticas de genocídio indígena tem sido traçadas por um governo federal movido por ideais da extrema direita: sistemático desmonte das instituições públicas como FUNAI (Fundação Nacional do Índio) e das políticas públicas garantidas pela constituição nacional como Saúde e Educação Intercultural e Bilíngue Indígena, tentativas de mudança das leis que regem os direitos ao território tradicional como as demarcações de terra indígena, diminuição da proteção de indígenas isolados e comunidades indígenas em situação de risco devidos a conflito de terra....

Ao mesmo tempo, estamos vivendo um desafiante movimento em nossa universidade, com a criação de reserva de vagas à indígenas em nossos cursos de graduação e pós-graduação, que chamamos no Brasil de Sistema de Cotas. Compreender o sistema de cotas universitárias como uma possibilidade de encontro com/entre povos leva-nos à imagem de uma flecha de duas pontas: como uma importante política de inclusão que dará espaço a uma população que ficou historicamente à margem das políticas de acesso acadêmico em nosso país, e também como uma possibilidade de a universidade e as ciências, em suas diversas áreas de conhecimento, reconhecerem que o diálogo com as formas indígenas de ver e pensar foi um caminho ainda pouco trilhado. E esse será um longo caminho a ser inventado na educação, nas artes, na filosofia... 
Como receber e se deixar atravessar por imagens, palavras e sons outros de povos secularmente silenciados? Como abrir neste mundo muitos outros mundos possíveis, pela arte do encontro na diferença? São estas inquietações que mobilizam pensamentos sobre as fronteiras férteis entre arte, educação, filosofia e povos indígenas brasileiros. Temos estudados alguns/algumas artistas e obras no cinema, na fotografia e nas artes visuais que se fazem a partir de encontros com povos indígenas. Dentre os artistas estudados, as obras da fotógrafa Cláudia Andujar, fruto de seu trabalho de criação de mais de 30 anos com o povo Yanomami, é referência e fonte de inspiração. Instigam-nos as transformações da obra desta artista sob a interferência dos modos de existência yanomami. Em diversos momentos de sua vida, Cláudia Andujar realizou experiências de criação com os Yanomami no sentido de envolver-se em suas narrativas, em suas cosmologias e em suas imagens. Entre desenhos, narrativas de sonhos e mitos, sua obra se faz em livros, exposições, curta metragens, videoinstalações em um movimento de criação dinâmico e vivo. Na obra MitopoemasYãnomam (ANDUJAR, 1979) organizada por Cláudia Andujar e traduzida Carlo Zacquini, os desenhos de sonhos e do mundo mítico yanomami foram ofertados pelos pajés Koromani Waica, Mamoke Rorowe, Kreptip Wakatautheri. Seus desenhos não representam o sonho, são traços, marcas entremeadas ao universo imagético dos grafismos yanomami. Deste olhar atento às cosmovisões e visualidades yanomami nasce uma obra atravessda por seus modos de existência, seus pontos de vista e de vida (COCCIA, 2018). Nestes encontros, abre-se uma zona de vizinhança entre visualidades distintas, pelo gesto de escuta de solidariedade entre a artista e os yanomami, cria-se uma causa comum. Uma força política outra.
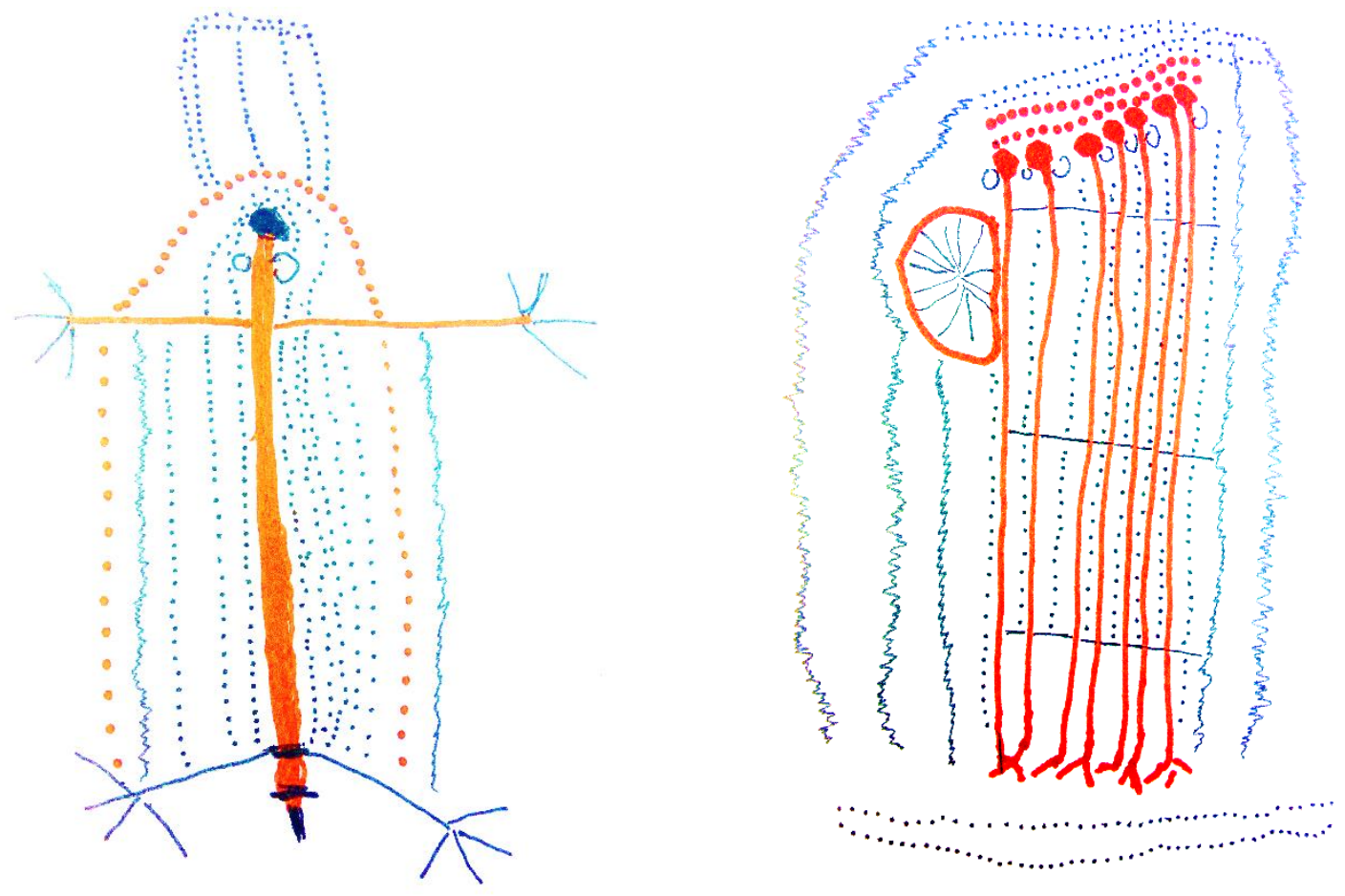

Imagem 1: Desenhos de Tanaki Xaxapanithéri - fonte: livro A Luta Yanomami

Andujar abre um fértil caminho a percorrer no entrecruzamento de nossas lógicas visuais e as teorias indígenas da imagem. Suas imagens percorrem a fenda entre imagens visíveis e imagens videntes, estão numa terceira via que se abre de forma imprevisível quando a arte se dispõe a encontrar. Suas imagens deixaram-se atravessar pela força de vida yanomami.

Cada ponto de vista é um mundo possível. Cada ponto de vista é um ponto de vida (COCCIA, 2018). Desejamos nos encontros de criação imagética com indígenas, e nas 
pesquisas que se desdobram deles, dizer menos sobre eles e mais a partir do encontro com suas forças de expressão e pensamento, seus mundos possíveis como nos convida o antropólogo brasileiro Eduardo Viveiros de Castro. Viveiros nos faz desafiantes convites: "Quando o propósito do pesquisador deixa de ser o de explicar, interpretar, contextualizar, racionalizar esse pensamento, e passa a ser o de o utilizar, tirar suas consequências, verificar os efeitos que ele pode produzir no nosso? O que acontece quando se leva o pensamento nativo a sério? O que é pensar o pensamento nativo?" (VIVEIROS DE CASTRO, 2002, p. 3). Como abrir-nos radicalmente a essa diferença no pensamento? Os indígenas oferecem-nos outras imagens, outras visualidades, mundos outros. Lançamos aqui nesta comunicação o desafio do entre imagens: escrever entre narrativas e imagens dos Kariri-Xocó e palavras dos filósofos Deleuze, Guattari e Emanuele Coccia. Nestas escritas deseja-se ramificar e crescer pelas frestas de pensamentos (ainda germinais) sobre o devir-planta e as entre imagens que nasceram dos encontros com os Kariri-Xocó.

\begin{abstract}
"Imaginemo-nos sem olhos. Ao redor, nem cores, nem formas. Nenhum desenho de silhueta. $\mathrm{O}$ mundo não se apresenta a nós como variedade de corpos e de intensidades de luz. É um corpo único, com diferentes graus de penetrabilidade. Imaginemo-nos sem ouvidos. Não há ruídos, não há música, não há poesia. Nenhuma linguagem que possamos compreender. Tudo não passa de uma agitação silenciosa de matérias. Imagine-nos sem pernas. Não podemos nos mexer ao menos que agora nos atinja [...] Imaginemos tudo isso e busquemos definir em que consistiria nossa experiência de estar no mundo. Imaginemos tudo isso e teremos uma ideia, por certa imprecisa e aproximativa, do mundo tal como se dá a ver e viver às plantas[...]. As plantas, representam um ponto de vista ou melhor um ponto de vida." (COCCIA, 2018, p. 1-2)
\end{abstract}

Em 2013 recebemos pela primeira vez a família Tinga que integra o grupo artístico Sabuká Kariri-Xocó em nossa cidade. Desde então criamos uma rede de apoio ao grupo, formada por professores, estudantes, artistas e ativistas da causa indígena para acolhê-los por alguns dias na cidade. A rede organiza encontros em escolas, universidades, centros culturais e possibilita diversos intercâmbios com crianças, jovens, educadores/as, artistas, ativistas, pesquisadores/as... Nestes primeiros encontros a força de seus corpos pintados, de suas danças e cantos, de suas artes materiais nos lançou a uma intensa criação fotográfica. Em 2015, no terceiro encontro anual, fizemos o convite a uma experiência fotográfica conjunta que se fez em dois movimentos: o primeiro foi a experiência de fotografar e o segundo de realizar intervenções - recortes, raspagens, desenhos - sobre um conjunto de fotografias que fizemos do grupo. Deste segundo movimento a visualidade dos grafismos deram contornos outros as superfícies fotográficas. As linhas de jenipapo - fruto que dá cor negra às pinturas corporais transbordaram seus corpos e invadiram as fotografias. A visualidade kariri-xocó entrelaçou-se com as formas das fotografias criando uma superfície imagética híbrida. Com a técnica de raspagem das imagens com esponjas de aço, abriram-se luzes outras, dando materialidade fotográfica a sonhos e as visagens. O pajé Pawana Crodi, após o encontro, olhando as criações deste primeiro ateliê disse: "É a arte e a imaginação dando forma a nossa realidade". 


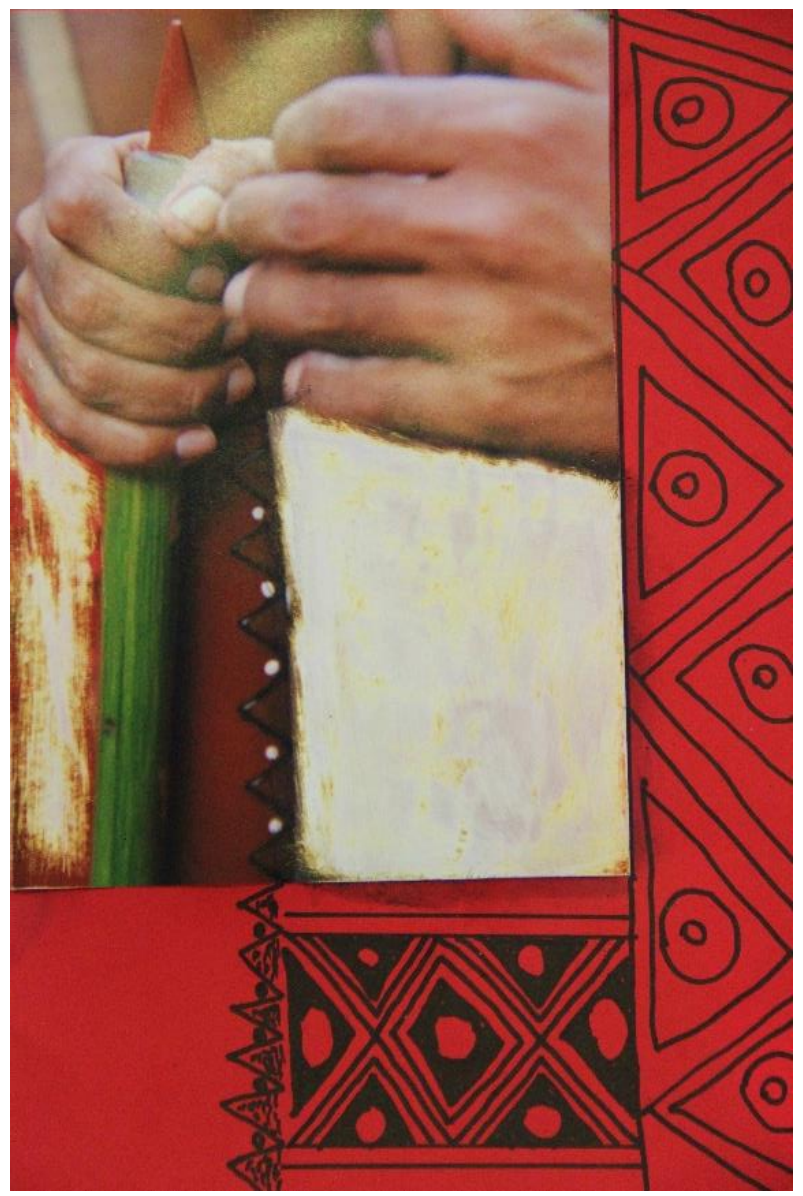

Imagem 2: criação de Dirã Kariri-Xocó sobre fotografia de Marli Wunder

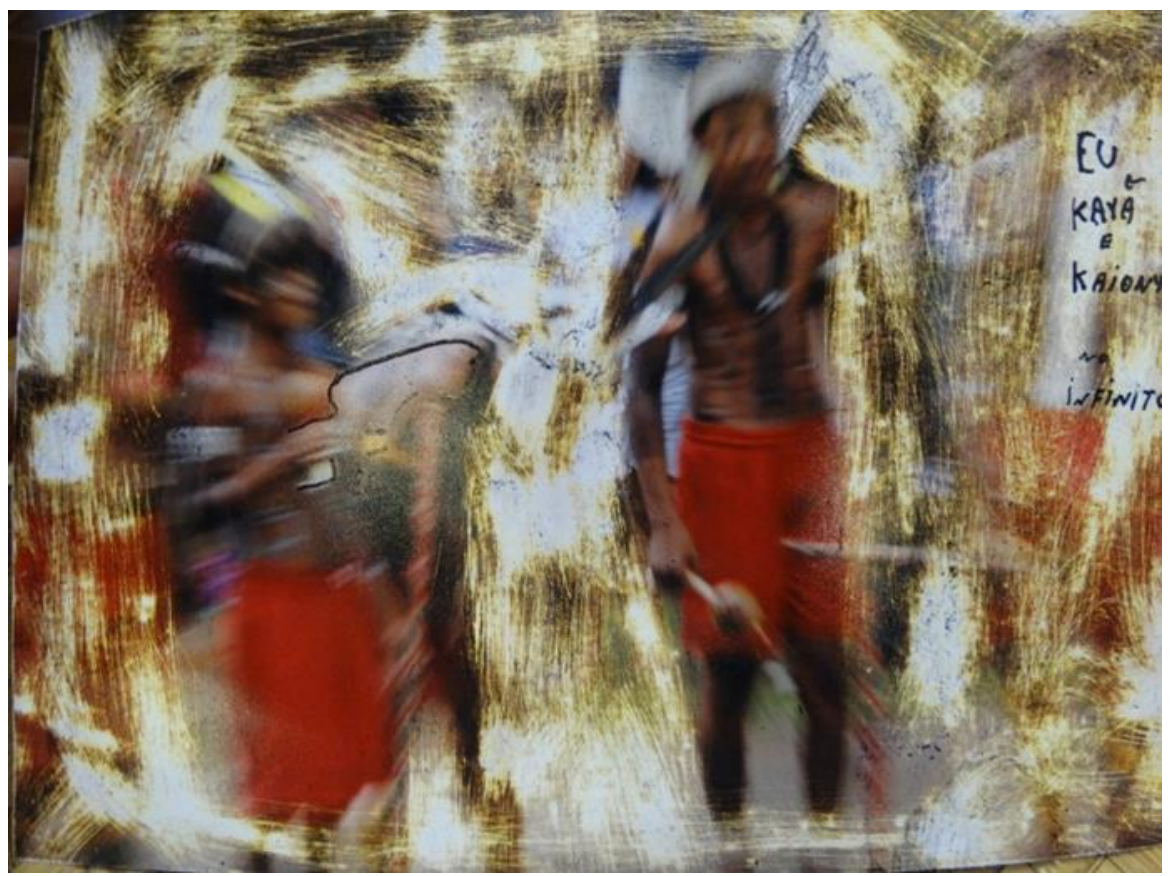

Imagem 3: criação de Pawana Crodi sobre fotografia de Marli Wunder 


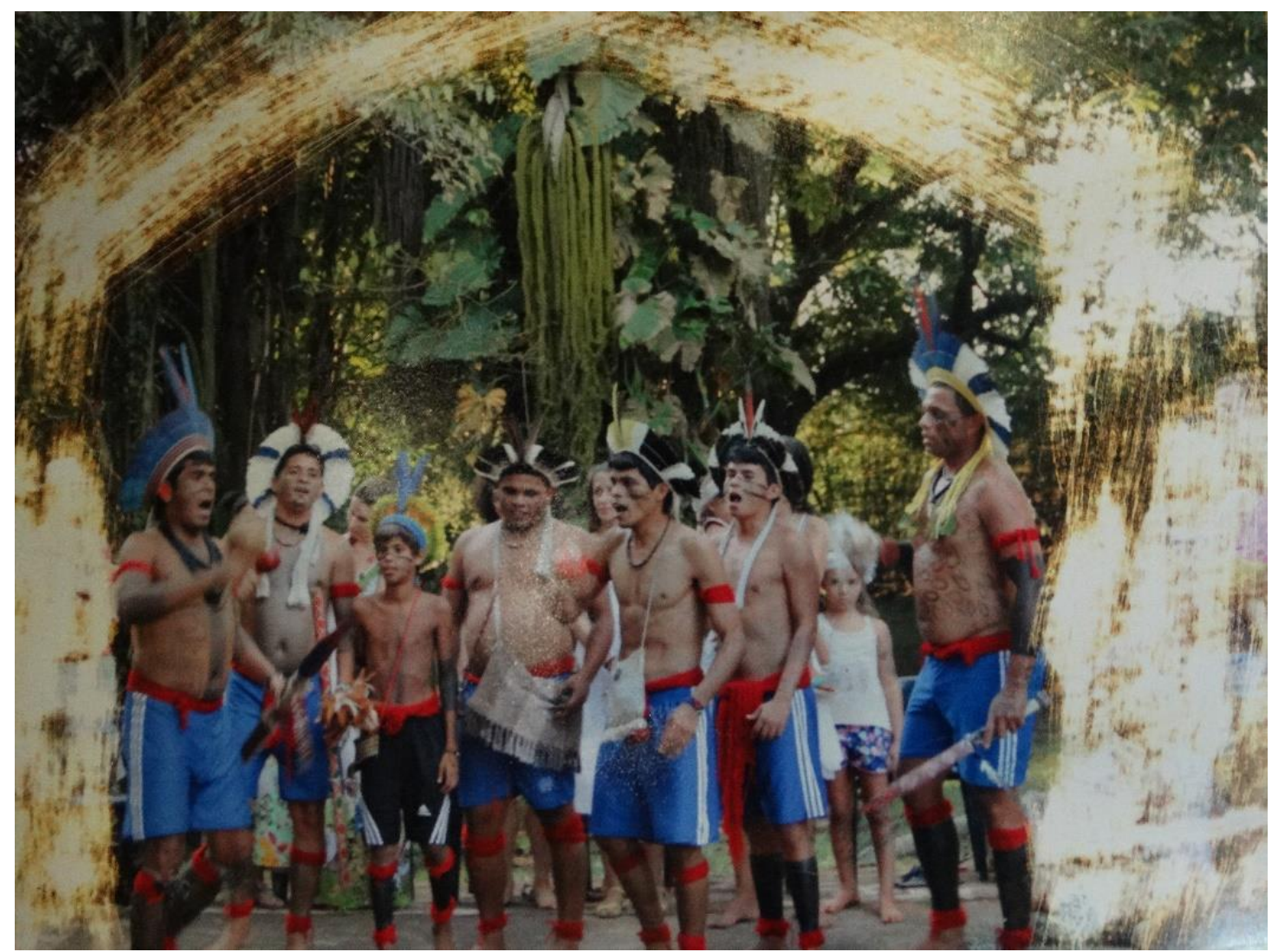

Imagem 4: criação deYaru Kariri-Xocó sobre fotografia de Marli Wunder

$\mathrm{Na}$ abertura entre o visível fotografável e o campo invisível do sonho, as criações abriram no corpo-fotografia um entre mundos. Para Deleuze e Guattari o devir define-se em um campo de multiplicidade, onde as forças que constituem o corpo entram em uma zona de vizinhança, fronteiriça, uma co-presença. Poderíamos pensar nestas imagens como uma zona de vizinhança? A imagem como um espaço ritual do encontro, a imagem como um devir, uma fronteira aberta?

Foi no primeiro movimento do ateliê de criação que o inesperado, o desdobramento mais radical da diferença, instaurou-se: na experiência de fotografar. Iniciamos com uma roda de conversa em que nós, pesquisadoras e fotógrafas, apresentamos nossos modos de criação com imagens. Falamos sobre os modos de compor luzes e sombras, cores, linhas e texturas a partir de uma pequena exposição. Fizemos convite para que também fotografassem e que, ao invés de colocarem atenção ao objeto/ser fotografados, se atentassem às luzes, sombras, cores e formas... No entanto, o convite pareceu sem sentido e nenhum deles se movimentou para realizar fotografias. Estávamos em um grande jardim, repleto de frondosas árvores em uma casa de cultura, o Centro Cultural Casarão, local onde o grupo se hospeda na cidade. Percebendo que a experimentação fotográfica precisaria ganhar outro caminho, e já conhecendo as fortes relações dos Kariri-Xocó com o mundo vegetal, perguntei: "E se vocês fotografassem aquilo que as plantas vêm? E se nos mostrassem nas fotografias o mundo na perspectiva de visão das plantas?" Começaram a rir e seguiram para um exercício de fotografar não o jardim, mas com jardim. A arte dos encontros se faz a cada passo, criações contínuas são exigidas em cada curva deste caminho. 

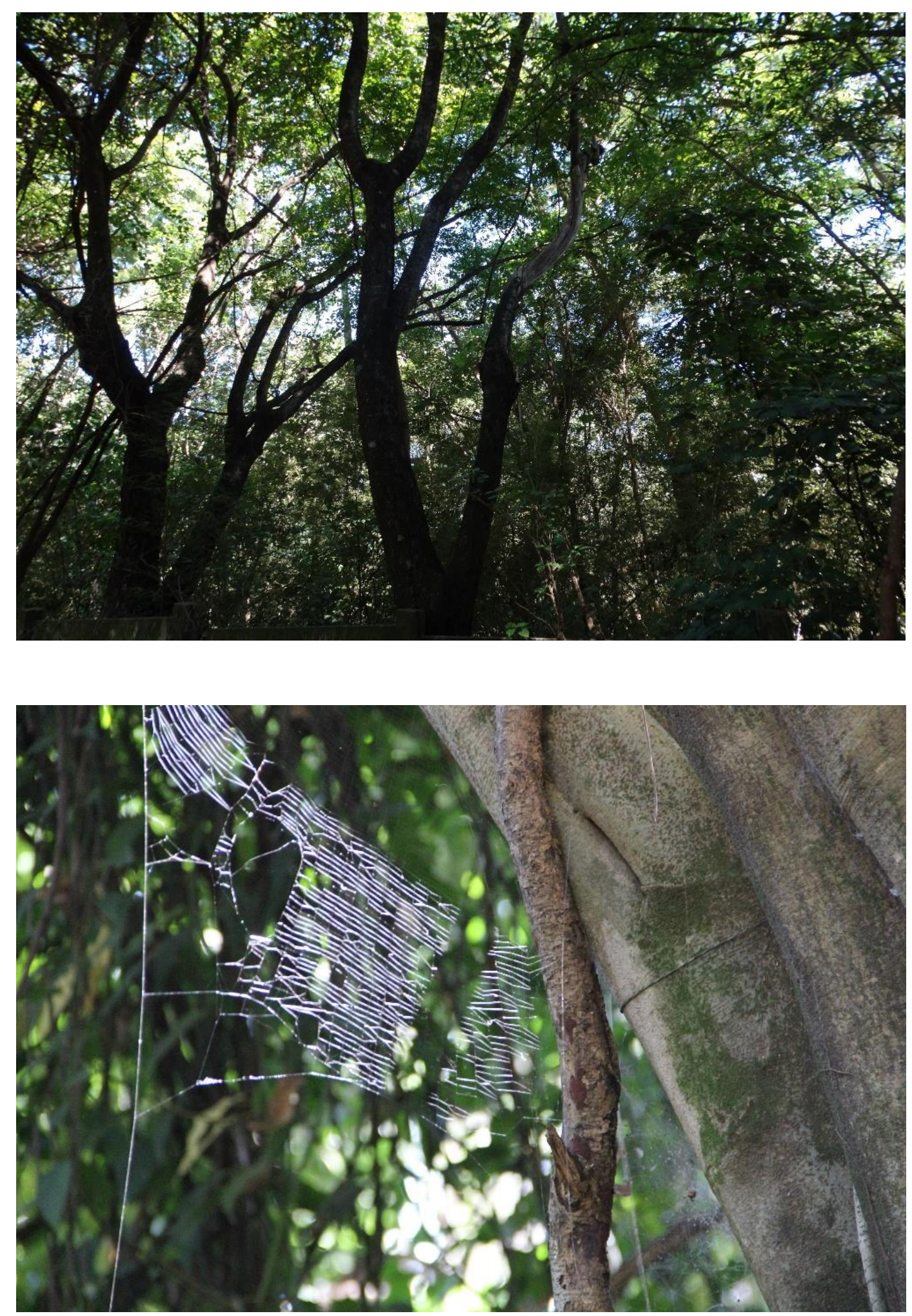

Imagem 5 e 6: fotografia de Kaony Kariri-Xocó 


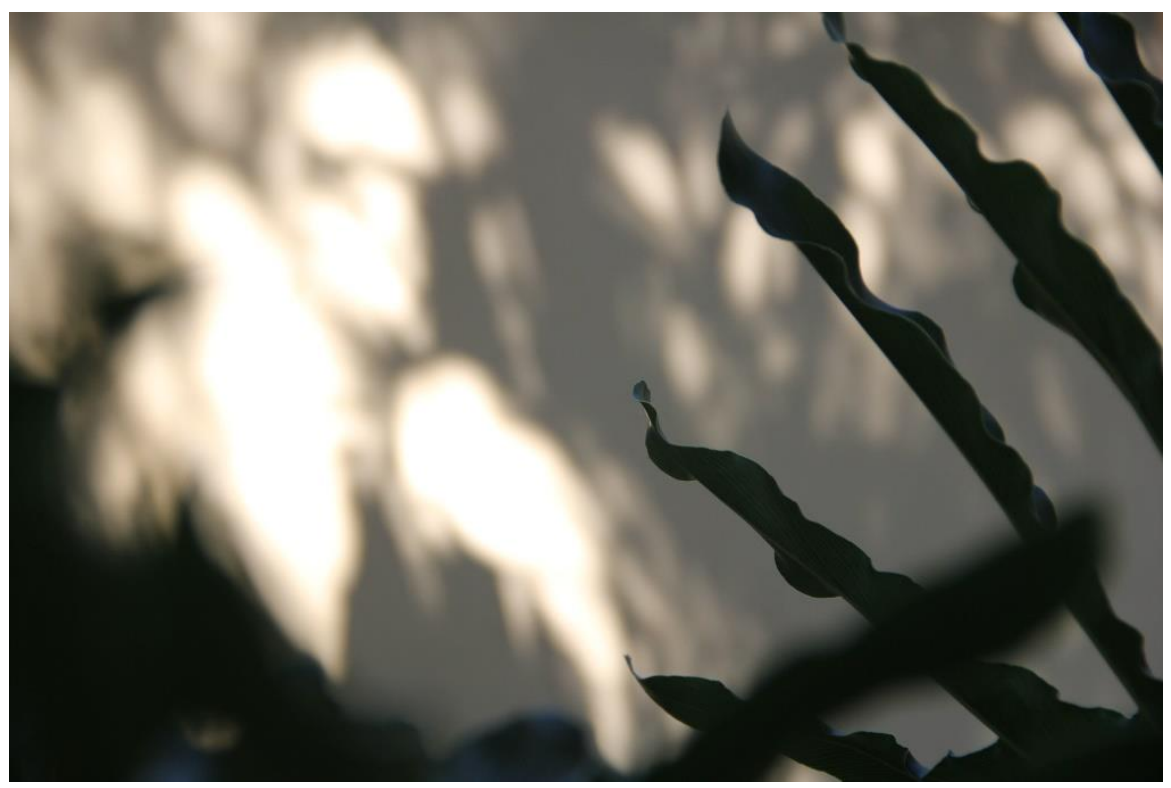

Imagens 7: fotografia de Pawana Crodi

Emanuele Coccia em seu livro a "Vidas das Plantas" (2018) propõe uma filosofia a partir daquilo que as plantas nos ensinam, pelo seu modo de estar no mundo, de habitar e gerar vida. Coccia propõe um pensar sob a perspectiva das plantas seria menos um modo de acessar seu ponto de vista, mas de acesso a seu ponto de vida. Sobre o modo planta de estar no mundo e de criar mundos escreve:

"As plantas têm, pela autotrofia, a capacidade transformar a energia solar dispersa sobre o cosmos em corpo vivo, a matéria disforme e disparatada do mudo em realidade coerente, ordenada e utilitária. Se às plantas que devemos perguntar o que é o mundo, é porque são elas que fazem o mundo. O mundo é para a grande maioria dos organismos, o produto da vida vegetal, o produto da colonização do planeta pelas plantas" (COCCIA, 2018, p. 15).

Coccia convida a uma inversão radical do pensamento em que humanos não são seres que vivem em paisagens vegetais e cultivam plantas, mas como um dos produtos da agricultura de biodiversidade realizada em milhões de anos pelos vegetais. Deixar-se atravessar e pensar a partir deste modo de existência vegetal, pode ser pensado como um devir planta do pensamento que abre para modos não humanos de individuação e para a criação de novos territórios, novas subjetividades. Cria um alargamento da ideia de viventes se ampliam para além do humano e nos convida a pensar o ponto de vida das plantas aqueles seres que nos possibilitam viver no espaço fluido de vida que é atmosfera. (COCCIA, 2018).

A inesperada entrada do devir-planta em no exercício fotográfico com os Kariri Xocó pode ser pensada como um ponto de partida para nossas experimentações que se deram entorno da criação de imagens do "mundo das plantas" deste povo em nossos ateliês experimentais. A pergunta que nos mobilizou foi: o que levou os Kariri-Xocó ao impulso alegre de fotografar o ponto de vista (ou de vida como propõem Coccia) das plantas? Fotografar o mundo pela perspectiva de uma planta é um exercício pouco provável em nosso regime de visualidade ocidental e beira o sem-sentido, quando entendemos que uma planta não tem órgãos de visão. Chamou-nos atenção a entrada imediata deles neste campo de possíveis. Que subjetividades outras a cosmovisão Kariri-xocó cria para que o devir-planta se faça presente e vivo? Como as relações que se estabelecem entre os Kariri-Xocó e o mundo das plantas possibilitam esta 
potente ação do devir-planta em seus processos de criação, em suas artes, e seus cantos, em seus grafismos? Para traçar o desafiante caminho de "pensar o pensamento nativo"(VIEIROS DE CASTRO, 2002) abrimos espaços/tempos de escuta. As memórias também encontraram sons e cores para árvores, as árvores contaram música. Fomos nos juntando às arvores, escutando as folhas e elas nos ouvindo atentas, o que contávamos delas.

Dé Kariri-Xocó tem voz de terra: "Às vezes eu me acordo, até de madrugada, e vou lá. Me sento e conto para a arvore meu sonho". E quando conversamos, quando a comunicação está lá, elas cantam e nos dão música." (Dé Kariri Xocó)

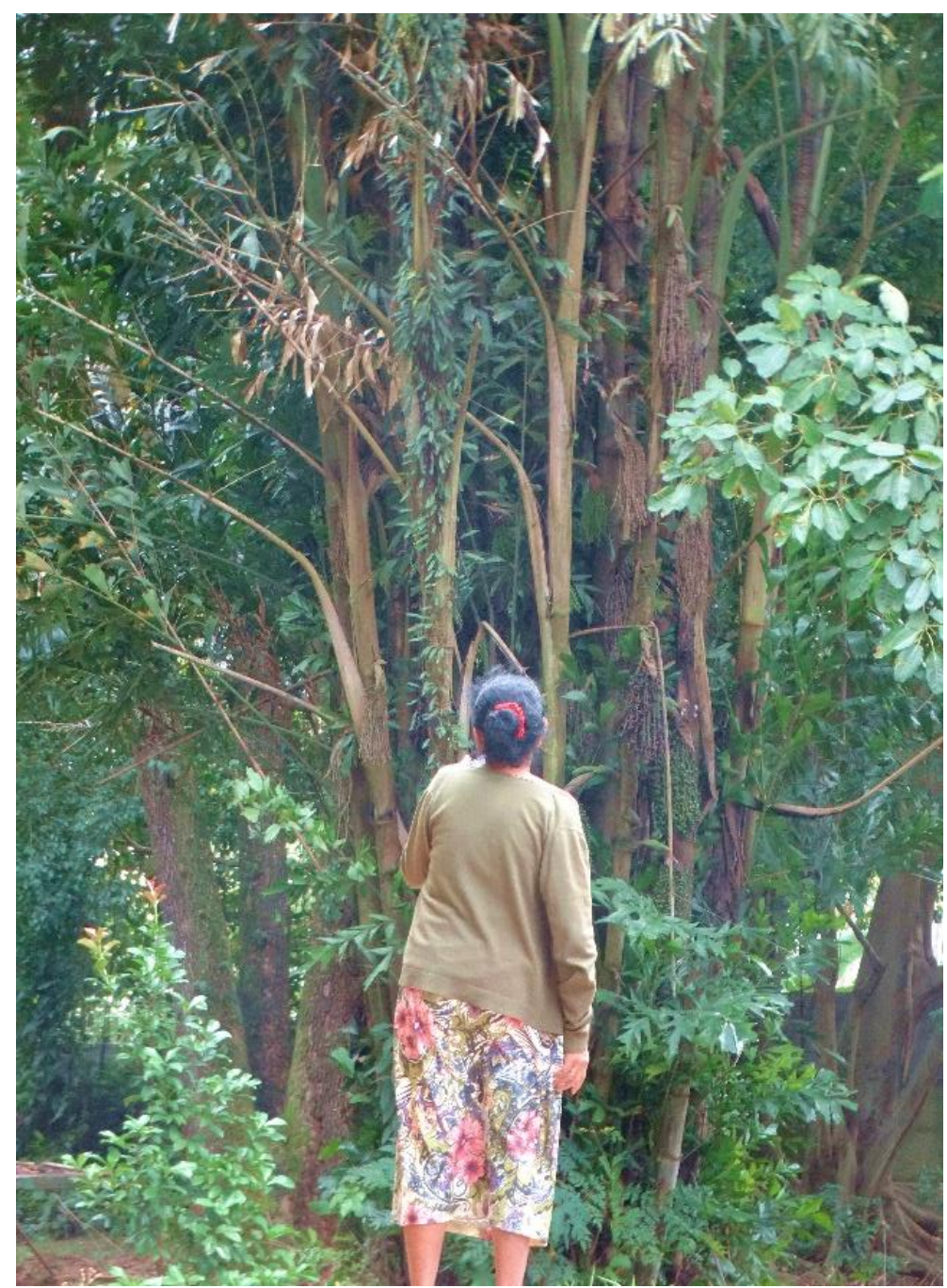

Imagem 8: fotografia de Alik Wunder

Kaony tem voz de folha: "Quando nós queremos entrar na mata para procurar um remédio, vamos lá pedimos autorização a ela para retirar aquela erva que temos necessidade. E ela então passa que nós podemos tirar. Esse é o contato que temos com as árvores”(Kaony Kariri-Xocó). 


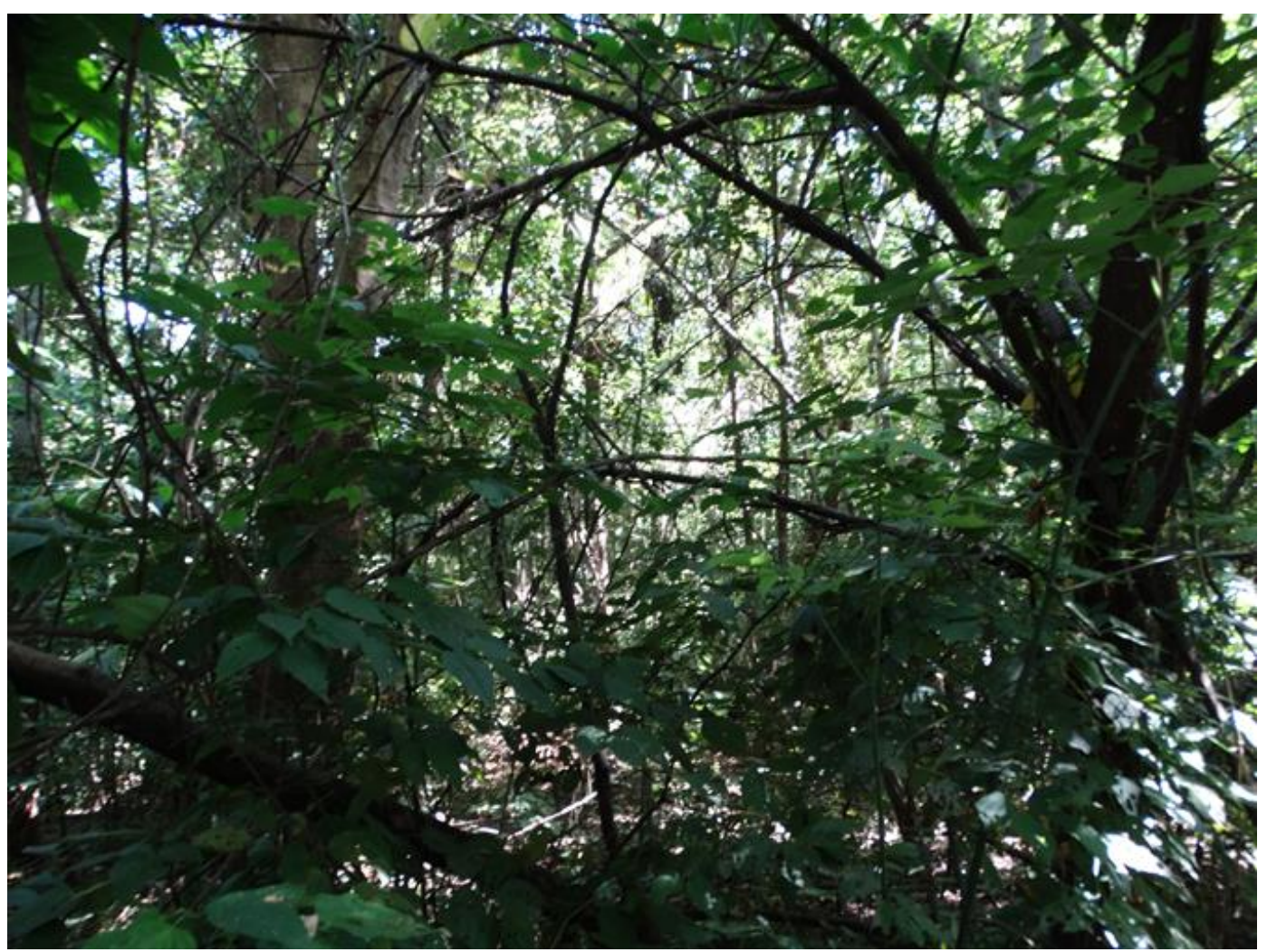

Imagem 9: fotografia de Kaony Kariri-Xocó

Pawana tem voz de raiz:“A gente entende a planta como nossa vida também. No mundo dela tem nossa mãe, nosso pai, nossos tios, tem aquela planta que acaricia a gente, tem aquela que aconselha, tem aquela que lapida também. Tem aquela que cuida, que cura. Com isso a gente passa a conhecer como é a vida dela, no mundo vegetal dela. Elas pedem e a gente sente. É o sentir, o perceber, porque a planta é um ser que tem vida, tem boca, tem olho, tem coração, tem tudo...”.(Pawanã Crodi Kariri-Xocó)

\begin{abstract}
"O perspectivismo ameríndio é a concepção indígena segundo a qual o mundo é povoado de outros sujeitos, agentes ou pessoas, além dos seres humanos e veem a realidade diferente dos seres humanos. A proposição presente nos mitos indígenas é: os animais e as plantas eram humanos e deixaram de sê-lo. Nas mitologias indígenas todo mundo é humano, apenas alguns desses humanos são menos humanos que os outros" (VIVEIROS DE CASTRO, 2007, p. 32 e 33).
\end{abstract}

Nesta metamorfose entre forma humana e não-humana dos regimes conceituais indígenas, há um modo radicalmente outro de compreender o que seja humanidade e natureza. Neste modo de pensar os animais e as plantas são ex-humanos, diferentemente de nossa cultura ocidental que concebe o humano como ex-animal. "Tudo isso senta um pressuposto fundamental de que o fundo comum da humanidade da animalidade não é, como para nós, a animalidade, mas a humanidade" (VIVEIROS DE CASTRO, 2007, p. 76). O perspectivismo ameríndio produz uma força filosófica que desorganiza o dualismo do pensamento ocidental, a relação entre "natureza" e "cultura" se faz radicalmente distinta. No pensamento ocidental há oposição e cisão entre "cultura" e "natureza", uma forma binária de demarcar o mundo. Colocar em desequilíbrio conceitos que nos parecem "naturais" faz pensar nas malhas que criam os opostos como verdades absolutas. Deleuze e Guattari descrevem um instigante modo de resistir a estas linhas de oposição binárias no texto "Micropolítica e Segmentaridade". Os 
autores afirmam que tudo é político e delineiam pensamentos sobre as micropolíticas e macropolíticas. As linhas duras e binárias da macropolítica são molares e se efetuam com mais força nas sociedades modernas, aquelas que tem em comum um Estado unificado. As linhas molares definem opostos como: verdadeiro-falso, cultura-natureza, homem-mulher, sujeito-objeto, selvagem-civilizado, passado-futuro. Forças molares que produzem linhas que desejam unificar o poder criando a partição do mundo em dualidades excludentes e desiguais. "Do ponto de vista da micropolítica, uma sociedade se define por suas linhas de fuga, que são moleculares. Sempre vaza ou foge alguma coisa que escapa às organizações binárias" (DELEUZE; GUATTARI, 1996, p. 94). As linhas moleculares potencializam a multiplicidade e se fazem mais intensas nas micropolíticas. Para os autores, as sociedades sem Estado, como as indígenas, possibilitam pensar conceitualmente nas linhas moleculares, nas variações flexíveis menos subordinadas à figura do poder unificado. Pelas segmentaridades flexíveis das sociedades sem Estado, as variações, as mutações, as ambiguidades são potencializadas. Abre-se a possibilidade de pensar pela multiplicidade e ambivalência: gente e bicho e planta e homem e mulher... Podemos pensar que o perspectivismo ameríndio produz uma força filosófica molecular nas linhas duras do pensamento dualista. Os diferentes povos indígenas nos oferecem, não apenas outras formas de relação com aquilo que chamamos de natureza, eles nos oferecem múltiplas naturezas. Nesta outra cosmovisão, os devires animais e vegetais parecem atuar com mais potência. O pensamento indígena ameríndio oferece-nos olhares que não se centram em um fundo comum, abrem fissuras na própria ideia de que há algo préexistente anterior aos olhos. Oferecem-nos um modo outro de pensar o próprio olhar, atravessado por perspectivas (consideradas por nós) não-humanas. Perguntamo-nos: como estes mundos poderiam intensificar as micropolíticas inventivas do pensamento?

Para os Kariri Xocó as árvores escutam sonhos, dão conselhos, castigam e curam, deixam conhecer seu mundo vegetal em um modo de conversação aberta... Há uma fronteira que se abre em momentos especiais: momentos de necessidade, de doença, de crises, enquanto se fuma o pawi, no ritual... eno ponto mais forte desta conversação, os cantos são dados pelas árvores como um ensinamento que vão além do uso material para a realização de curas. Há um devir-planta que se passa nesta zona fronteiriça, desta subjetividade ambivalente genteplanta que se faz em sonho, em intuição, no momento que as linhas da pintura corporal aparecem nos corpos... Os corpos são a todo tempo riscados com a fruta do jenipapo e fazem do corpo um devir-planta, as marcas das pinturas não significam, instauram devires na pele: o devir cobra, devir-tartaruga, linhas que abrem zonas de vizinhança com outros reinos. Parece haver nas várias expressões da arte kariri-xocó, na sua arte material, nos cantos um devir vegetal que se dá nesta fronteira aberta entre o que chamamos de humano e inumano. Os indígenas nos trazem imagens de uma natureza que passa longe de ser apenas fonte de recursos. As ervas, as árvores e a floresta são povoadas de intencionalidades, sujeitos, seres, espíritos que cuidam há milhares de anos de tudo o que existe. Devires que proliferam alegria, germina e ramificam modos outros de estar no mundo, outras formas de pensar e criar.

\section{Referências}

ANDUJAR, Cláudia. Mitopoemas Yãnomam. Tradução Carlo Zacquini. São Paulo: Olivetti do Brasil, 1979.

ANDUJAR, Cláudia. A Luta Yanomami. NOGUEIRA, Thiago (Org.). São Paulo: IMS, 2018. 
COCCIA, Emanuele. A Vida das plantas: uma metafísica da mistura. Tradução Fernando Sheibe. Florianópolis: Cultura e Barbárie, 2018.

DELEUZE, G.; GUATARRI, F. Mil Platôs: capitalismo e esquizofrenia. Rio de Janeiro: Ed. 34, 1996. v. 3.

VIVEIROS DE CASTRO, Eduardo. O nativo relativo. Revista Mana, v. 8, n. 1. Rio de Janeiro, 2002

VIVEIROS DE CASTRO, Eduardo. Eduardo Viveiros de Castro. SZTUTMAN, Renato (Org.). Coleção Encontros. Rio de Janeiro: Azougue, 2008.

\section{Sobre a autora}

Graduou-se em Biologia pela Universidade Estadual de Campinas (Unicamp), tem Mestrado, Doutorado e Pós-doutorado em Educação pela Faculdade de Educação da Unicamp. É professora/pesquisadora Faculdade de Educação da Unicamp. Realiza pesquisas no Laboratório de Estudos Audiovisuais OLHO relacionando educação, artes visuais e afroindígenas e filosofia contemporânea. E-mail: awunder@unicamp.br. 